\title{
Effect DEHP plasticizer on MDA concentration and histopathological changes in Contronix contronix japonica
}

\author{
A.Z. Hamoodi $(1)$ and S.S. Al-Mahmood $(\mathbb{D}$ \\ Department of Pathology and Poultry Diseases, College of Veterinary Medicine, University of Mosul, Mosul, Iraq
}

\begin{tabular}{l} 
Article information \\
\hline Article history: \\
Received January 27, 2021 \\
Accepted July 11, 2021 \\
Available online November 10, 2021 \\
\hline Keywords: \\
DEHP \\
Quail \\
Histopathology \\
MDA \\
MEHP \\
\hline Correspondence: \\
S.S. Al-Mahmood \\
saevan981@ @ahoo.com
\end{tabular}

\begin{abstract}
In this experiment, we aimed to recorded the effect of chronic oral exposure to DEHP on lipid peroxidation and histopathological lesions induced in different organs. A total of 150 quail chick divided into two groups ( 75 quail's chicks at each group), control group left without any treatment all time, the second group was orally administrated 5\% of DEHP $(278.05 \mathrm{mg} / \mathrm{kg} \mathrm{bw})$ three times per week and lasted for 60 days. At 30 and 60 days old, a total number of 25 from both groups were euthanized. Blood samples were collected to determine the serum concentration of DEHP and mono ethyl hexyl phthalate (MEHP), liver and kidney to estimate tissue concentration of malondialdehyde (MDA), samples from different organs for histopathological examination. The result showed that the concentration of DEHP and MEHP in blood's serum and concentration of MDA in liver and kidney significantly increased with time in comparison with the control group; besides, oral administration of DEHP induced sever pathological lesions, in brain, aorta, intestines, liver, lung, ovary and testis. In conclusion, the DEHP and its metabolic product MEHP significantly increased in serum and cause significant increase in concertation of MDA in liver and kidney tissues, produces a significant histopathological change in brain, aorta, liver, intestine, lung, ovary and testis that can cause a life-threatening condition.
\end{abstract}

DOI: 10.33899/ijvs.2021.129395.1645, (A)Athors, 2022, College of Veterinary Medicine, University of Mosul.

This is an open access article under the CC BY 4.0 license (http://creativecommons.org/licenses/by/4.0/).

\section{Introduction}

DEHP is considered an environmental pollutant widely distributed worldwide, causing severe health issues for humans and animals (1). DEHP is a member of phthalic acid products used in polyvinyl chloride as a master plasticizer to produce the desired flexibility (2). It is odorless and colorless, easily mix with water and lipids solvents, also, to its use as a plasticizer, it adds to industrial color, engine oils, a preservative in cosmetics products; also its previously used in tubes and blood bags (3), due to this general industrial uses of DEHP the annual world production is estimated by 20 billion tons (4). DEHP is widely used in the poultry industry as an additive to water and feeding supplies, also used in cages of layer hens, drugs and vaccine plastic containers, as a preservative to feed additives, wooden litter to prevent worm infestation, and in the main tanker for water supplies that made from poly vinyl chloride (PVC) (5). Many previous studies have been conducted on the toxicity of DEHP in different types of aviary species, included quails, one of these studies estimated the median lethal dose (LD50) by $5574.1 \mathrm{mg} / \mathrm{kg}$ of body weight (6), another study showed that the liver and kidney consider the main sites were the pathological lesions have been recorded (7). DEHP has a unique chemical reaction with materials added to them; it does not react with other molecules' chemical bonds, but it covers other materials' molecular composition. This reaction is easily solved by exposure to sunlight or temperature above $25^{\circ} \mathrm{C}$ to water, air, and soil of the surrounding environment, considered the primary source of toxicity DEHP to other livings (8). We aimed to investigate the pathology associated with oral DEHP administration in the brain, intestines, lungs, testis, and ovary in addition to liver and kidney of quails, also study the effect of prolonged exposure to DEHP in quails on 
peroxidation factors such as MDA, also the effect of DEHP administration on the production properties of quails such as food consumption, food conversion ratio and egg production using $5 \%$ of LDso of DEHP.

\section{Materials and methods}

\section{Quails}

A total of 150 Japanese quails (Contronix contronix japonica) weighted 9 grams \pm 2 grams have been used, were obtained from Directory of Agriculture Researches, Nineveh province at the age of 1 day, they were kept at all experimental period into divided ground lead cages.

\section{DEHP properties}

The DEHP used in this experiment were obtained from Himedia company (India), its characterized by colorless and odorless, fast dissolving in water and lipids, with chemical equation $\mathrm{C}_{12} \mathrm{H}_{14} \mathrm{O}_{4}$ with molecular weight $222.24 \mathrm{~g} / \mathrm{mol}$, and the concentration of DEHP in this solution was estimated by 1 grams/ 1 milliliter of solution.

\section{DEHP dose and administration}

Depending on previous scientific studies, the oral LD50 of DEHP during 24 hours was estimated at $5574.1 \mathrm{mg} / \mathrm{kg}$ of quail's body weight $(6,7)$. The current study used $5 \%$ of $\mathrm{LD}_{\mathbf{5 0}}$ of DEHP, which is estimated by $278.05 \mathrm{mg} / \mathrm{kg}$ bw, the dose volume is 0.3 milliliters/quail by oral gavage needle (7).

\section{Experimental designs}

A 150 quail were used and divided randomly into two groups (75 quails to each group), the control group kept without any administration to DEHP all time, the treated group (G2) were orally administrated 5\% of DEHP at a dose of $278.05 \mathrm{mg} / \mathrm{kg}$ bw in quails, and the administration volume is 0.3 milliliters/quail using oral gavage, this administration is started from the first day of age and continued until 60 days of ages, the DEHP is administrated three times per week and lasted for 60 days.

\section{Experimental criteria}

At every 2,30 and 60 days of quails age and experimental days, 25 quails from each group were euthanized. Blood was collected to obtained serum tissue samples from the brain, intestines, lungs, testis, ovary, liver, and kidney were fixed in $10 \%$ formalin (9), samples from liver and kidney were collected and freeze at $-20{ }^{\circ} \mathrm{C}$ then homogenized using manual homogenizer to estimated MDA using manual photometric method by spectrophotometer at $450 \mathrm{~nm}$ wave length (10). Also, serum level of DEHP and MEHP were estimated using indirect ELISA test (11).

\section{Histopathology}

The samples of brain, intestines, lungs, testis, ovary, liver, and kidney were collected from both groups and fixed in $10 \%$ neutral buffered formalin for 72 hours, late a represented sample were having been chosen from these organs and dehydrated with ethyl alcohol, cleared by xylene, infiltrated and embedded by paraffin wax at $58{ }^{\circ} \mathrm{C}$ (9). The tissue embedded in paraffin were section at $6 \mu \mathrm{m}$ and stained with Harris' hematoxylin and alcoholic eosin (12).

\section{Statistical analysis}

The means were statistically analyzed using SPSS version 19.0, and the post hock test of One Way ANOVA is Duncan's test. The * symbol mean the treated group and significantly differ from control group, while vertical different letters means a significant difference at $\mathrm{P}<0.05$ (13).

\section{Results}

The mean concentration of MDA in the liver tissue was significantly increased in the treated group with time progress, in which the one-day-old MDA was 4.837 $\mu \mathrm{mol} / \mathrm{gram}$ wet tissue then increase to reach up to 25.264 $\mu \mathrm{mol} / \mathrm{gram}$ wet tissue at 60 days of treatment with DEHP; also the mean concentration was higher than in control group which ranged between $4.431-5.216 \mu \mathrm{mol} / \mathrm{gram}$ wet tissue (Table 1).

A similar result was reported in kidney tissue were the concentration of MDA increase from $47.178 \mu \mathrm{mol} / \mathrm{gram}$ wet tissue on the first day of the experiment and to reach 87.284 $\mu \mathrm{mol} / \mathrm{gram}$ wet tissue, which significantly differs from oneday-old in the same group and comparison with the control group at 30, and 60 days (Table 2).

Table 1: MDA tissue concentration in liver ( $\mu \mathrm{mol} / \mathrm{gram}$ wet tissue)

\begin{tabular}{lcc}
\hline Days & Control & Treatment \\
\hline 1 day old & $4.431 \pm 0.120^{\mathrm{a}}$ & $4.837 \pm 0.217^{\mathrm{c}}$ \\
30 days old & $4.932 \pm 0.124^{\mathrm{a}}$ & $17.108 \pm 1.153^{\mathrm{b}^{*}}$ \\
60 days old & $5.216 \pm 0.269^{\mathrm{a}}$ & $25.264 \pm 1.344^{\mathrm{a}^{*}}$ \\
\hline
\end{tabular}

Table 2: MDA tissue concentration in the kidney $(\mu \mathrm{mol} / \mathrm{gram}$ wet tissue)

\begin{tabular}{lcc}
\hline Days & Control & Treatment \\
\hline 1 day old & $46.278 \pm 2.347^{\mathrm{a}}$ & $47.178 \pm 2.644^{\mathrm{c}}$ \\
30 days old & $47.745 \pm 3.158^{\mathrm{a}}$ & $65.896 \pm 5.616^{\mathrm{b}^{*}}$ \\
60 days old & $45.472 \pm 2.311^{\mathrm{a}}$ & $87.284 \pm 2.313^{\mathrm{a}^{*}}$ \\
\hline
\end{tabular}

The result of the mean concentration of DEHP in the serum of quails showed that the concentration of DEHP was increased significantly from $0.163 \mu \mathrm{g} / \mathrm{ml}$ at one-day-old to reach up to $12.184 \mu \mathrm{g} / \mathrm{ml}$ after 60 days of DEHP treatment, this increase was differing significantly in comparison with the control group at 30 and 60 days (Table 3).

The result of MEHP a most important DEHP metabolites in the blood significantly increased from $0.041 \mu \mathrm{g} / \mathrm{ml}$ at one- 
day-old to reach up to $1.932 \mu \mathrm{g} / \mathrm{ml}$ after 60 days of DEHP treatment in quail's blood serum; also, this increase was found to significantly differ in comparison with control groups at 30 and 60 days (Table 4).

Table 3: DEHP concentration in quail's serum $(\mu \mathrm{g} / \mathrm{ml})$

\begin{tabular}{lcc}
\hline Days & Control & Treatment \\
\hline 1 day old & $0.156 \pm 0.021^{\mathrm{a}}$ & $0.163 \pm 0.024^{\mathrm{c}}$ \\
30 days old & $0.138 \pm 0.034^{\mathrm{a}}$ & $2.791 \pm 0.094^{\mathrm{b}^{*}}$ \\
60 days old & $0.121 \pm 0.204^{\mathrm{a}}$ & $12.184 \pm 0.093^{\mathrm{a}^{*}}$ \\
\hline
\end{tabular}

Table 4: MEHP concentration in quail's serum $(\mu \mathrm{g} / \mathrm{ml})$

\begin{tabular}{lcc}
\hline & Control & Treatment \\
\hline 1 day old & $0.039 \pm 0.008^{\mathrm{a}}$ & $0.041 \pm 0.009^{\mathrm{c}}$ \\
30 days old & $0.042 \pm 0.008^{\mathrm{a}}$ & $0.574 \pm 0.010^{\mathrm{b}^{*}}$ \\
60 days old & $0.036 \pm 0.009^{\mathrm{a}}$ & $1.932 \pm 0.017^{\mathrm{a}^{*}}$ \\
\hline
\end{tabular}

\section{Histopathology \\ 30 days of DEHP administration}

Section of cerebellum showed accumulation of glial cells in focal patterns represented as glial nodules in cerebellum cortex which composed from reactive glial cell-associated with macrophages, in addition to widespread of vasogenic edema described as a distention in perivascular space that filled with fluids oozing and leakage from blood vessels and accumulated in space like lesions. The aorta section showed the accumulation of lipid-laden cells, which appears as clear vacuoles in the intimal and medial layer of blood vessels; these cells can be termed as foam cells macrophages where contains lipid vacuoles. Hepatic tissue showed portal fibrosis due to collagen deposition and the accumulation of macrophages and lymphocytes around portal areas. The hepatocytes showed small size clear vacuoles in their cytoplasm be explained as fatty degeneration. In the intestines, the section showed marked mucinous degeneration to intestinal glands located in the submucosa layer, in addition to cellular debris due to the sloughing of necrotic villi. Lung sections showed marked accumulation of red blood cells in the interstitial tissue associated with marked infiltration of inflammatory cells such as macrophages around blood vessels (Figure 1).

\section{0 days of DEHP administration}

Section of quail's brain showed an increase in the thickness of meninges as a response to cellular injury with widespread vasogenic edema in the cerebrum cortex associated with hyperplasia and hypertrophy of Purkinje cells in cerebellum. The wall of aorta showed the formation of atheroma plaques in the wall of aorta present in tunica intima cause pressing and reduction in the lumen diameter with the presence of a high number of foam cells. The liver sections showed hyperplasia of bile canaliculi in the portal area and fatty degeneration in affected hepatocytes as small clear vacuoles in different circular shape and sizes, causing pressing the nucleus to cellular membranes. The submucosa layer of small intestines showed mucinous degeneration associated with necrosis in the whole villi with slough and desquamation of these necrotic cells as cellular debris in the intestinal lumen. There is a fusion of two or more necrotic villi into one large thick villi in severe cases. The lung section showed focal infiltration of mononuclear cells at peribronchial position, associated with pulmonary hemorrhage in the interstitial tissue of lung with macrophages' infiltration between alveoli. Section of testes showed complete stopping of spermatogenesis in which the seminal tubules appear empty from mature spermatozoa, on other hands the section of ovaries showed complete absence of primordial follicles in ovarian tissues which represented the first stage of developing follicles, also the granular cells of ovary's parenchyma showed vacuolar degeneration with infiltration of macrophages in tissue of ovary, with hemorrhage (Figure 2).

\section{Discussion}

The result of the current study showed that oral administration of DEHP for 30 and 60 days to quails would cause a significant increase in the level of MDA in the tissue of the liver and kidney in comparison with the control group and these significant differences were continuous to increase in correlation with increased exposure to this plasticizer, this result was agreed with Zhang et al. (14) which they measure the level of MDA in quail's liver after exposure to 250 and $1000 \mathrm{mg} / \mathrm{kg}$ of body weight for 45 days, in addition, another study conduct by Yu et al. (15) measured the level of MDA in the tissue of spleen in quail showed a significant increase after oral administration of DEHP at 250 and $750 \mathrm{mg} / \mathrm{kg}$ of body weight. MDA consider as a marker for lipid peroxidation, especially in cell walls and in cytoplasmic organelles (16); the increased level of MDA in liver and kidney tissues of quills that administrated DEHP giver a serious indicator about the status of lipid peroxidation in these tissues, this high concentration in tissues will lead to direct damages to the cell membrane of cells lead to losing the control permeability and osmotic regulation ended by losing their function which appears as degenerative and necrotic changes, and this changes were approved by the histopathological study which recorded severe damage to tissues indicated as fatty degeneration and hyperplasia of bile canaliculi in addition to severe changes in walls of major blood vessels (17).

The result of histopathological examination showed the presence of fatty degeneration and hyperplasia of bile ducts; this result was found similar to that obtained by Zhao et al. (18), which recorded the presence of fatty changes, these changes were correlated with the concentration of administrated DEHP and the time of administration, and this find was also observed in our study in which the lesions were 
started as mild fatty degeneration with few small vacuoles inside hepatocytes and with time progress the complete transformation of hepatocytes to shape similar to adipocytes were observed in association with hyperplasia in the number of bile ducts in portal area and infiltration of mononuclear inflammatory cell especially macrophages. In the brain the most articles showed hypertrophy of Purkinje cells in the cerebellum, and thus appear as an increase in the size of the cell with the eosinophilic appearance of the cytoplasm; also, there is hyperplasia of these cells due to irritation to brain layers (19), these result of other articles were recorded in our study in addition to the presence of vasogenic edema with presences of glial nodule that composed from glial cell aggregation in response to DEHP toxicity these changes associated with meningitis that recorded after 60 days of DEHP administration. The result of current study considered the first article that reports the lesions induced by DEHP in the aorta of quails, in which there is an aggregation of foam cell in the tunica intima and media of the aorta walls, these cells are macrophages where migrate in the walls of the aorta in response to increase lipid peroxidation as a result of DEHP toxicity, these cell phagocytes these lipid into their cytoplasm to remove lipid from this area which gives these macrophages a foam-like appearance, in addition, the long exposure to DEHP cause in atheroma formation the wall of aorta which causes compression to the underlying layer and destroy these layer especially tunica intima (20).
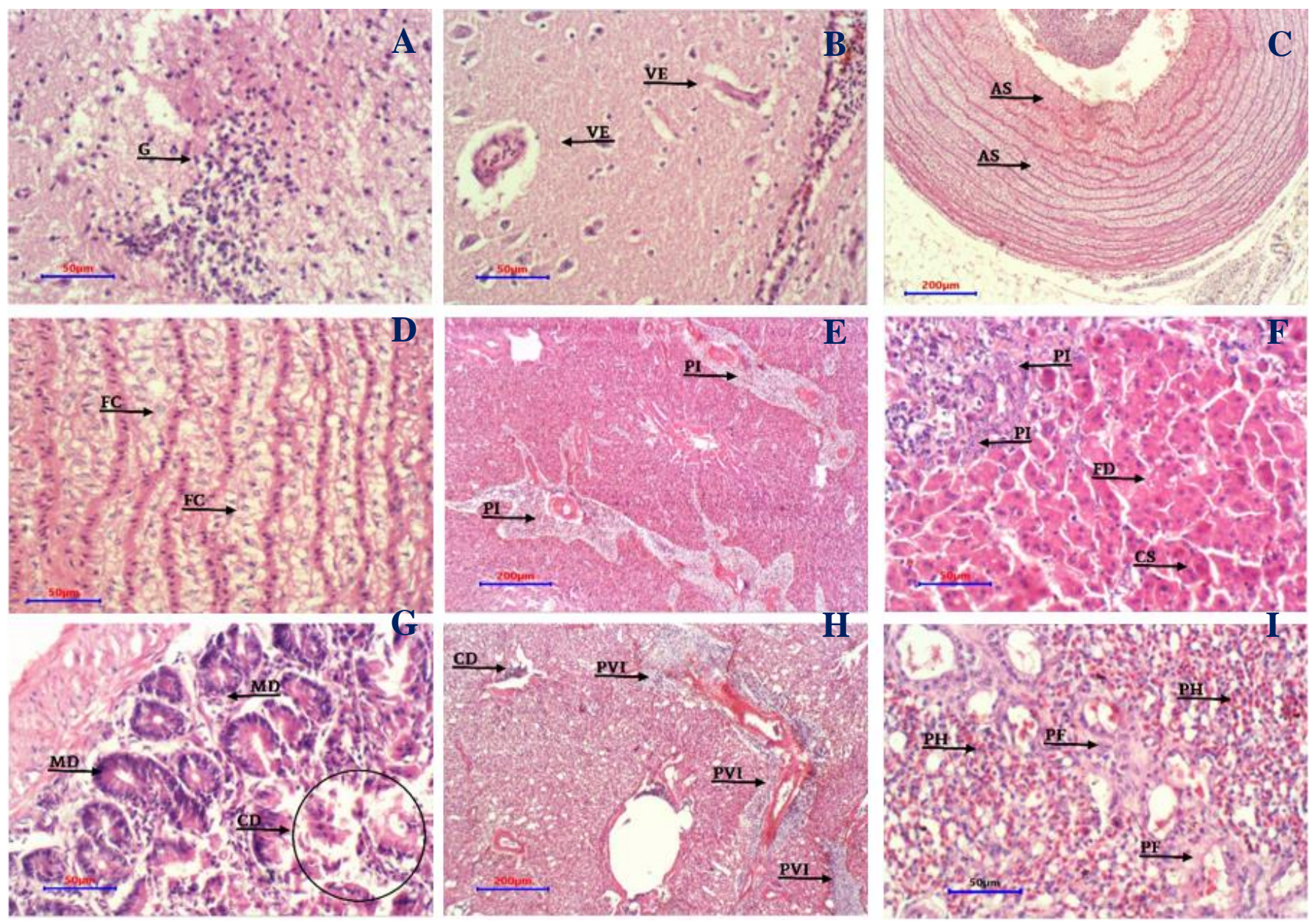

Figure 1: Tissue sections from brain ( $\mathrm{A}$ and $\mathrm{B})$, aorta $(\mathrm{C}$ and $\mathrm{D})$, liver (E and $\mathrm{F})$, intestine $(\mathrm{G})$, lung $(\mathrm{H}$ and $\mathrm{I})$ from treated quails with DEHP after 30 days of administration. (G) glial nodule in brain steam, (VE) vasogenic edema in cerebrum cortex, (AS) atherosclerosis in aorta, (FC) foam macrophages present in tunica media and tunica intima of the affected aorta, (PI) hepatic portal infiltration of mononuclear inflammatory cell, (FD) fatty degeneration in affected hepatocytes as some clear vacuoles, (CS) cloudy sell swelling in hepatocytes, (MD) mucinous degeneration in intestinal villi, (CD) cellular debris sloughed from necrotic villi and lung tissue, (PVI) perivascular cuffing of mononuclear inflammatory cell in lung tissue, (PH) pulmonary hemorrhage in the interstitial tissue of the lung, and (PF) pulmonary fibrosis represented by collagen deposition around the affect alveoli. H\&E. 

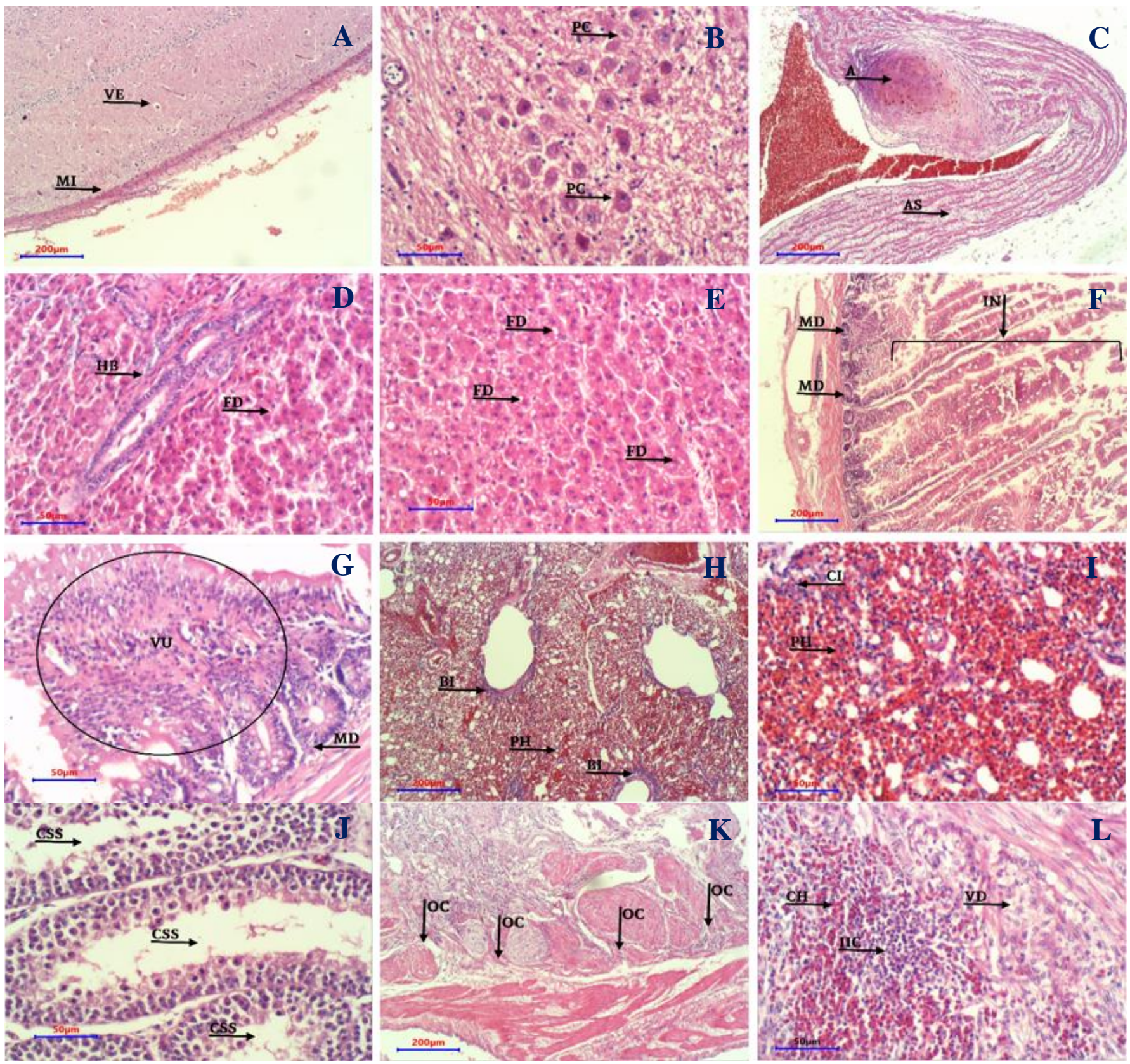

Figure 2: Tissue sections from brain (A and B), aorta (C), liver (D and E), intestine (F and G), lung (H and I), testis (J), ovary ( $\mathrm{K}$ and $\mathrm{L}$ ) from treated quails with DEHP after 60 days of administration. (MI) increase in thickness of meninges, (VE) vasogenic edema in cerebrum cortex, (PC) hyperplasia and hypertrophy of Purkinje cells, (A) formation of atheroma plaques in wall of aorta, (AS) atherosclerosis in aorta, (HB) hyperplasia of bile canaliculi in portal area, (FD) fatty degeneration in affected hepatocytes as some clear vacuoles, (MD) mucinous degeneration in intestinal villi, (IN) complete villus necrosis and appears as cellular debris, (VU) fusion of two or more villus into one large villi due to continuous irritation, (BI) peri-bronchial cuffing of mononuclear inflammatory cell in lung tissue, $(\mathrm{PH})$ pulmonary hemorrhage in the interstitial tissue of lung, $(\mathrm{CI})$ infiltration of mononuclear inflammatory cell in the pulmonary interstitial tissue, (CSS) complete stopping of spermatogenesis and the seminal tubules appear empty from mature spermatozoa, (PF) complete absent of primordial follicles in ovarian tissues, (VD) vacuolar degeneration in granular cells in ovary, (OC) with complete absence of primordial follicles in the ovary cortex, (IIC) infiltration of inflammatory cells in the tissue of ovary, and $(\mathrm{CH})$ ovarian hemorrhage. H\&E. 
The sections of intestines showed coagulative intestinal necrosis to villi that sloughed and appeared as cellular debris accumulated in the lumen associated with mucinous degeneration and fusion of two or more necrotic villi into one big villus; this can occur as a result of a direct action of DEHP that induce irreversible cellular injury that causes necrosis of this affected villi (21). Sections of the lung showed massive hemorrhage with infiltration of inflammatory cells; these results are agreed with a study conduct by Atia and Abdel-Gawad (22) have they indicated infiltration of inflammatory cells, especially macrophages, with an increase in a deposition to collagen fibers around the bronchial and interstitial tissue as a response to irritation induced by DEHP and their metabolic products such as MEHP (22). Section of testis showed a complete absence of spermatids and stopping the spermatogenesis process; these results were found agreed with many articles that showed DEHP produced testicular toxicity and damages to tubules and spermatogenesis in all stages; also, DEHP induces vacuolar degeneration in Sertoli and Leydig cells (23). Section of quail's ovary showed complete absence of primordial follicles which consider the first step in developing follicles with hemorrhages, vacuolar degeneration in granular cell of interstitial tissue with infiltration of inflammatory cells, these result can be explained by the effect of MEHP the main metabolic of DEHP that cause decrease and stop estradiol production from ovary the activate peroxisomes receptors in the granulosa cells of developing follicles cause them to undergo apoptosis, all these outcomes suggest that the primary site of toxicity for DEHP is the granulosa cell of growing pre-ovulatory follicles which cause complete absent of these primordial follicles and lead to cystic ovary in cases where the exposure occur after puberty, on other hand the ovary from quails were they exposed to DEHP since one day old their ovary showed complete absent of growing and ovulatory follicles (24), the same results were have been recorded by other studies $(25,26)$ in which the vacuolar degeneration in granular cell layer of ovary with hemorrhage are the most significant outcomes in DEHP toxicity in rats.

\section{Conclusion}

In conclusion, the DEHP and its metabolic product MEHP significantly increased in serum and cause significant increase in concertation of MDA in liver and kidney tissues, produces a significant histopathological change in brain, aorta, liver, intestine, lung, ovary and testis that can cause a life-threatening condition.

\section{Acknowledgments}

We wish to express our complements to College of Veterinary Medicine, University of Mosul, to support current study.

\section{Conflict of interest}

The authors declare that they did not have any conflict of interest regarding publishing nor funding of this manuscript.

\section{References}

1. Rowdhwal SS, Chen J. Toxic effects of di-2-ethylhexyl phthalate: An overview. Bio Med Res Inter. 2018;1-10. Doi: 10.1155/2018/1750368

2. Chiellini F, Ferri M, Morelli A, Dipaola L, Latini G. Perspectives on alternatives to phthalate plasticized poly (vinyl chloride) in medical devices applications. Prog Polymer Sci. 2013;38(7):1067-1088. Doi: 10.1016/j.progpolymsci.2013.03.001

3. National Center for Biotechnology Information. PubChem Compound Summary for CID 8343, Bis (2-ethylhexyl) phthalate. 2021:1-92. [available at]

4. Wang Y, Zhu H, Kannan K. A review of biomonitoring of phthalate exposures. Toxics. 2019;7(2):21. Doi: 10.3390/toxics7020021

5. Cao XL. Phthalate esters in foods: Sources, occurrence, and analytical methods. Comp Rev Food Sci Food Safety. 2010:9(1):21-43. Doi: 10.1111/j.1541-4337.2009.00093.x

6. Al-Mahmood SS, Al-Abady SM. Pathological study of subchronic oral toxicity induced by Di (2- ethyl hexyl) phthalate in Japanese quails. Iraqi J Vet Sci. 2017;31(2):67-71. Doi: 10.33899/ijvs.2017.145567

7. Al-Mahmood SS, Al-Abady SM. Pathological study of acute oral toxicity induced by plasticizer di (2- ethyl hexyl) phthalate in japanese common quails Coturnix coturnix japanies. Iraqi $\mathrm{J}$ Vet Sci. 2017;31(1):17-24. Doi: 10.33899/ijvs.2017.126714

8. Veiga M, Bohrer D, Nascimento PC, Ramirez AG, Carvalho LM, Binotto R. Migration of phthalate-based plasticizers from PVC and nonPVC containers and medical devices. J Brazilian Chem Soc. 2012;23(1):72-77. Doi: 10.1590/S0103-50532012000100011

9. Al-Ajeli RR, Al-Qadhi AS, Al-Mahmood SS, Alkattan LM. Pathological study of neoplasms surgically excised from animals attended the veterinary teaching hospital. Iraqi J Vet Sci. 2021;35(1):914. Doi: 10.33899 /ijvs.2019.126188.1260

10. D'souza D, Subhas BG, Shetty SR, Balan P. Estimation of serum malondialdehyde in potentially malignant disorders and postantioxidant treated patients: A biochemical study. Contemp Clin Dent. 2012;3(4):448-51. Doi: 10.4103/0976-237X.107438

11. Tipple TE, Rogers LK. Methods for the determination of plasma or tissue malondialdehyde levels. Methods Mol Biol. 2012;889:315-24. Doi: $10.1007 / 978-1-61779-867-2 \_20$

12. Al-Mahmood SS. Improving light microscopic detection of collagen by trichrome stain modification. Iraqi J Vet Sci. 2020;34(2):273-281. Doi: 10.33899/ijvs.2019.126176.1256

13. Petrie A, Watson P. Statistics for veterinary and animal science. $3^{\text {rd }}$ ed. USA: Blackwell Publishing Ltd; 2013.

14. Zhang Q, Zhao Y, Talukder M, Han Y, Zhang C, Li XN, Li JL. Di(2ethylhexyl) phthalate induced hepatotoxicity in quail (Coturnix japonica) via modulating the mitochondrial unfolded protein response and $\mathrm{NRF}_{2}$ mediated antioxidant defense. Sci Total Environ. 2019;651:885-894. Doi: 10.1016/j.scitotenv.2018.09.211

15. Yu L, Li HX, Guo JY, Huang YQ, Wang H, Talukder M, Li JL. Di (2ethyl hexyl) phthalate (DEHP)-induced spleen toxicity in quail (Coturnix japonica) via disturbing Nrf2-mediated defense response. Environ Pollution. 2019;251:984-989. Doi: 10.1016/j.envpol.2019.05.061

16. Ayala A, Munoz MF, Arguelles S. Lipid peroxidation: Production, metabolism, and signaling mechanisms of malondialdehyde and 4hydroxy-2-nonenal. Oxidat Med Cell Longevity. 2014;1-31. Doi: $10.1155 / 2014 / 360438$

17. Forman HJ, Zhang H, Rinna A. Malondialdehyde: Overview of its protective roles, measurement, and biosynthesis. Mol Aspects Med. 2009;30(1-2):1-12. Doi: 10.1016/j.mam.2008.08.006

18. Zhao Y, Fan JH, Luo Y, Talukder M, Li XN, Zuo YZ, Li JL. Di-(2ethylhexyl) phthalate (DEHP)-induced hepatotoxicity in quail 
(Coturnix japonica) via suppression of the heat shock response. Chemosphere. 2019;5(1):2-9. Doi: 10.1016/j.chemosphere.2019.04.172

19. Du ZH, Xia J, Sun XC, Li XN, Zhang C, Zhao HS, Li JL. A novel nuclear xenobiotic receptors (AhR/PXR/CAR)-mediated mechanism of DEHP-induced cerebellar toxicity in quails (Coturnix japonica) via disrupting CYP enzyme system homeostasis. Environ Pollution. 2017;226:435-443. Doi: 10.1016/j.envpol.2017.04.015

20. Alfarisi HA, Mohamed ZH, Ibrahim MB. Basic pathogenic mechanisms of atherosclerosis. Egyptian J Basic Appl Sci. 2020;7(1):116-125. Doi: 10.1080/2314808x.2020.1769913

21. Zachary JF, McGavin MD. Pathologic Basis of Veterinary Disease. $5^{\text {th }}$ ed. New York: Elsevier; 2017. 1-56 p.

22. Atia T, Abdel-Gawad S. Pulmonary toxicity induced by exposure to phthalates, an experimental study. Inhalat Toxicol. 2019;209:1-8. Doi: 10.1080/08958378.2019.1695025

23. Park JD, Habeebu SS, Klaassen CD. Testicular toxicity of di-(2ethylhexyl) phthalate in young Sprague-Dawley rats. Toxicol. 2002;171(2-3):105-115. Doi: $10.1016 / \mathrm{s} 0300-483 \mathrm{x}(01) 00567-4$

24. Lovekamp-Swan T, Davis BJ. Mechanisms of Phthalate Ester Toxicity in the Female Reproductive System. Environ Heal Perspect. 2002;111(2):139-145. Doi: 10.1289/ehp.5658

25. Li XN, Li HX, Yang TN, Li XW, Huang YQ, Zhu SY, Li JL. Di-(2ethylhexyl) phthalate induced developmental abnormalities of the ovary in quail (Coturnix japonica) via disruption of the hypothalamicpituitary-ovarian axis. Sci Total Environ. 202;140293. Doi: 10.1016/j.scitotenv.2020.140293

26. Liu, JC, Lai, FN, Li, L. Di (2-ethylhexyl) phthalate exposure impairs meiotic progression and DNA damage repair in fetal mouse oocytes in vitro. Cell Death Dis. 2017;8:e2966. Doi: 10.1038/cddis.2017.350

\section{تأثير ملان ثنائي أثثيل هكسيل الفثالات على تركيز المالوندالديهايد والتغيرات المرضية في السمان الثيل الثنائع الياباني}

أوس زهير حمودي و سيثان سعد المحمود

فرع الأمراض وأمراض الدواجن، كلية الطب البيطري، جامعة

الموصل، الموصل، العراق أرن اصن

الخلاصة

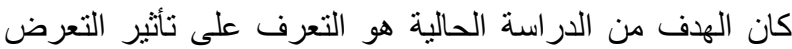

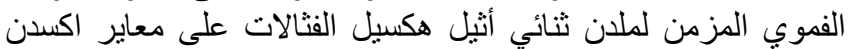
الدهون والتغير ات المرضية في أعضاء مختلفة في السمان. تم استخدام

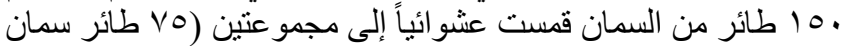

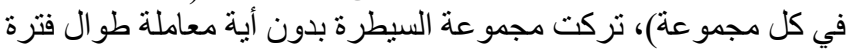

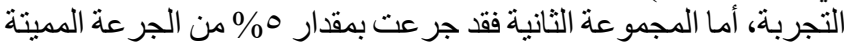

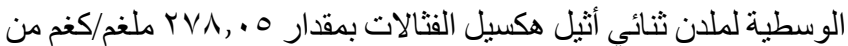

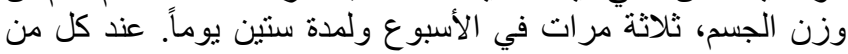

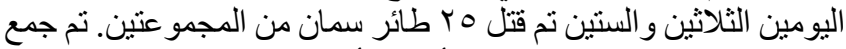

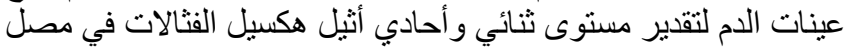

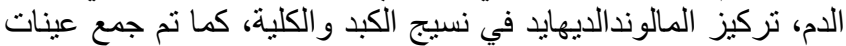

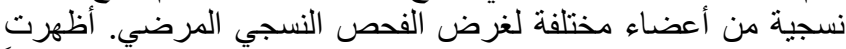
النتائج أن تركيز ثنائي و أحادي أثنيل هكسيل الفثالات في مصل ألثي الدم فضلاً

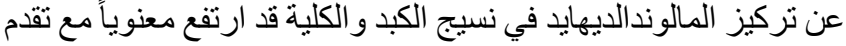

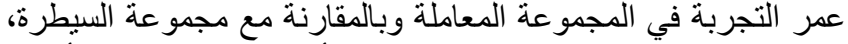

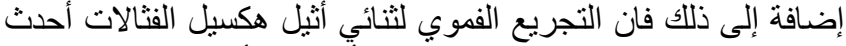

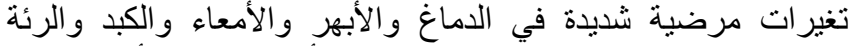
و المبيض و الخصية. نستنتج من هذه الدراسة أن أن ملدن ثنائي أثنيل هكسيل

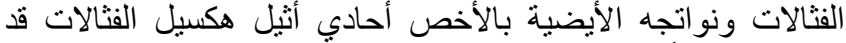

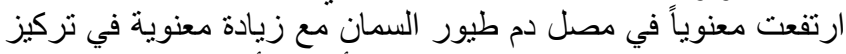

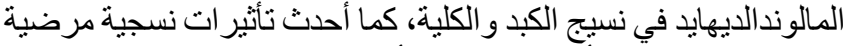

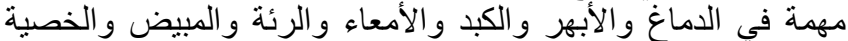
و التي تسبب مرض مهدد للحياة. 